\title{
Growth and feed utilization of the Nile tilapia fry pre-exposured to different water temperatures and hormone $17 \alpha$ methyltestosterone
}

\author{
Hosam M. Agouz
}

Central lab of aquaculture research, Abassa, Abou-Hammad, Sharkia, Egypt

\section{ABSTRACT}

The effect of water temperatures in combination with or without hormone $17 \alpha$ methyltestosterone application for different periods (1, 2, 3 and 4 weeks) on sex ratio and survival rate of $O$. niloticus fry were investigated. Three rearing temperatures $(25$, 30 or $30^{\circ} \mathrm{C}$ ) were tested; within each rearing treatment two levels of $17 \alpha$ methyltestosterone ( 0 or $60 \mathrm{mg} / \mathrm{kg}$ basal diet) were used. Sex ratio and survival rate of O. niloticus fry were determined after 1, 2, 3 and 4 weeks. Therefore, 24 groups $(3 \times 2$ $\times 4)$ were tested. At the end of this experiment, sex reversed fry were chosen at random from each group and stocked in $72 \mathrm{~L}$ aquaria $(3$ replicates for each group, $3 \times 24)$ and used to investigate the effect of rearing water temperature in combination with or without hormone application for different periods (1, 2, 3 and 4 weeks) on growth performance and feed utilization of $O$. niloticus fry during one month after treatment period.

The highest final body weight (BW), body length (BL), weight gain (WG), specific growth rate (SGR) and the worst feed conversion ratio (FCR) were obtained for fry reared (pre-exposured) at $35^{\circ} \mathrm{C}$ and fed on the diet supplemented by $60 \mathrm{mg}$ $17 \alpha-$ MT for one week and the lowest final BW, BL, WG, SGR and the best FCR were recorded for the control fry group (reared at $25^{\circ} \mathrm{C}$ and fed on the diet free from $17 \alpha$ MT for two weeks) and the same trend was also observed for tilapia fry pre-exposured to each of water temperature and $17 \alpha-\mathrm{MT}$ for three or four weeks. For the control, fry group rearing periods $(1,2,3$ or 4 weeks) did not affect the final BW, BL, WG, SGR or FCR of growing the Nile tilapia fry while, increasing the rearing period for $\mathrm{C} 35 \mathrm{H} 1$ gradually increased these parameters.

Keywords: pre-exposured, water temperature, hormone ( $17 \alpha$ methyltestosterone) Nile tilapia, growth performance, feed utilization

\section{INTRODUCTION}

Tilapias (Oreochromis niloticus) are a paradox in reproduction. The relative fecundity of $O$. niloticus species is low; 6,000-13,000 eggs/ $/ \mathrm{kg} / \mathrm{spawn}$. However, this is compensated by high survival rate and its iteroparity nature. Ideally, a fish species used in aquaculture is not allowed to reproduce in the culture environment before reaching market size. This phenomenon presents a significant challenge to the fish culturist. Most tilapia species often reach maturity within 6-8 months of hatching at a size often less than $100 \mathrm{~g}$. Under favourable conditions tilapia will start to reproduce leading to intraspecific competition hence stunted growth and become unmarketable (Beaven and Muposhi 2012).

All male culture of tilapia is preferred because of their fast growth. Several techniques have been used to produce monosex tilapia to control unwanted reproduction and among these include; manual sexing (Guerrero, 1982); hybridization (Hickling, 1960), genetic manipulation (Pandian and Varadaraj 1988, Soltan et al., 1999 and Abdel-Hakim et al., 2000); and sex reversal through sex oestrogenic hormone administration (Guerrero, 1982 and Soltan et al., 2013). 
Hormone treatment does not alter the genotype of the fish but directs the expression of the phenotype. Production of all male population through administration of androgen (17 $\alpha-\mathrm{MT})$ is considered to be the most effective and economically feasible method for obtaining all male tilapia populations (Guerrero and Guerrero 1988). Recently hatched tilapia fry do not have developed gonads such that it is possible to intervene at this early point in the life history and direct gonadal development to produce monosex populations. Exogenous steroids given during the gonadal development period can control the phenotype overriding the expression of the genotypically determined sex.

Some studies provided evidence that water temperature also governed the phenotypic sex of Oreochromis spp. A vast majority of experiments demonstrated that high temperatures favoured the production of (almost) monosex male progenies (O. niloticus: Baroiller et al., 1995: 1996 a \& b; O. aureus: Baras et al., 2000 \& Soltan et al., 2013). Except for some strains (Trewavas, 1983), $36-37^{\circ} \mathrm{C}$ is close to the upper incipient lethal temperature of O. niloticus (Balarin and Hatton, 1979), and above the thermal optimum for its growth (Melard, 1986).

Therefore, this study aimed to evaluate growth performance and feed utilization of O. niloticus sex reversed fry by rearing in different water temperature or hormone treatments for different periods.

\section{MATERIALS AND METHODS}

The present experiment was carried out at the hatchery unit at the experimental station of the World Fish Center, Abbassa, Abou-Hammad, Sharkia, Egypt to investigate the effect of rearing water temperature in combination with or without hormone $17 \alpha$ methyltestosterone application for different periods $(1,2,3$ and 4 weeks) on growth performance and feed utilization of sex reversed $O$. nioticus fry.

\section{Experimental fish:}

In previous experiment (Soltan et al., 2013), we investigated the effect of rearing in different water temperature in combination with or without hormone application for different periods (1, 2, 3 and 4 weeks) on sex ratio and survival rate of $O$. niloticus fry as the following:

T1: $\mathrm{C} 25 \mathrm{H} 0$ fry reared at $25^{\circ} \mathrm{C}$ and fed $17 \alpha-\mathrm{MT}$ free diet.

$\mathrm{T} 2$ : $\mathrm{C} 25 \mathrm{H} 1$ fry reared at $25^{\circ} \mathrm{C}$ and fed $60 \mathrm{mg} / \mathrm{kg}$ diet $17 \alpha-\mathrm{MT}$ supplemented diet.

T3: $\mathrm{C} 30 \mathrm{H} 0$ fry reared at $30^{\circ} \mathrm{C}$ and fed $17 \alpha-\mathrm{MT}$ free diet.

T4: $\mathrm{C} 30 \mathrm{H} 1$ fry reared at $30^{\circ} \mathrm{C}$ and fed $60 \mathrm{mg} / \mathrm{kg}$ diet $17 \alpha-\mathrm{MT}$ supplemented diet.

T5: C35H0 fry reared at $35^{\circ} \mathrm{C}$ and fed $17 \alpha-\mathrm{MT}$ free diet.

T6: $\mathrm{C} 35 \mathrm{H} 1$ fry reared at $35^{\circ} \mathrm{C}$ and fed $60 \mathrm{mg} / \mathrm{kg}$ diet $17 \alpha$-MT supplemented diet

At the end of this experiment sex ratio and survival rate were determined and sex rversed fry were chosen at random from each group (24 group, 6 treatments $\times 4$ periods) and stocked in $72 \mathrm{~L}$ aquaria ( 3 replicates for each group, $3 \times 24)$. Each aquarim was stocked with 15 fish therefore a total number of 1080 fish were used in the present study.

\section{Basal diet and fish feeding:}

Fish feed was formulated in the fish preparation Lab of the Worldfish center. Thomes-Willey Laboratory Mill Model 4 grinder was used for grinding the corn to small granules of $0.5 \mathrm{~mm}$ mesh. Ingredients of the feed were mixed and formulated using Hobarts mixer (model D300T) for 15 minutes. Oils, starch, mineral mixture and vitamins were added gradually to ingredient in the mixer. The mixed ingredients were then pelletted using Thomas-Willey laboratory Mill model 4 to form feed pellets. 
The basal diet was prepared by thoroughly mixing of the ingredients (Table 1). Water was added to the ingredients of each diet for mixing these ingredients and then dried. After drying, the diets were broken up and sieved into the convenient pellet size. Fish were given the experimental diets 6 day/week at a daily rate of $3 \%$ of total biomass (twice daily at $9.00 \mathrm{am}$ and $3.00 \mathrm{pm}$ ) till the end of experimental period. Every two weeks, fish were taken from each aquarium then weighted and the amount of feed was adjusted according to the changes in body weight throughout the experimental period.

Table 1: Formulation and composition of the artificial diet used for $O$. niloticus.

\begin{tabular}{|c|c|c|}
\hline & Ingredients & $\%$ \\
\hline Fish meal $(65 \%)$ & & 38 \\
\hline Soy bean meal (44\%) & & 30 \\
\hline Yellow corn & & 23 \\
\hline Bran & & 3.5 \\
\hline Vegetable oil & & 3 \\
\hline vitamins \&minerals mixture $^{1}$ & & 2.2 \\
\hline Ascorbic acid & & 0.3 \\
\hline Sum & & 100 \\
\hline Crude protein & & 40.2 \\
\hline Metabolizable energy (Kcal/kg feed) & & 2895 \\
\hline $\mathrm{P} / \mathrm{E}$ ratio (mg ptotein $/ \mathrm{kcal}$ ) & & 138.86 \\
\hline
\end{tabular}

1 Vitamin \& mineral mixture/kg premix : Vitamin D3, 0.8 million IU; A, 4.8 million IU; E, $4 \mathrm{~g} ; \mathrm{K}$, $0.8 \mathrm{~g}$; B1, $0.4 \mathrm{~g}$; Riboflavin, $1.6 \mathrm{~g}$; B6, $0.6 \mathrm{~g}, \mathrm{~B} 12,4 \mathrm{mg}$; Pantothenic acid, $4 \mathrm{~g}$; Nicotinic acid, $8 \mathrm{~g}$; Folic acid, $0.4 \mathrm{~g}$ Biotin, $20 \mathrm{mg}$, Mn, $22 \mathrm{~g}$; Zn, $22 \mathrm{~g} ; \mathrm{Fe}, 12 \mathrm{~g}$; Cu, $4 \mathrm{~g}$; I, $0.4 \mathrm{~g}$, Selenium, $0.4 \mathrm{~g}$ and Co, $4.8 \mathrm{mg}$.

\section{Growth performance and feed utilization parameters:}

Growth performance and feed utilization parameters were calculated as follows:

Weight gain $=\mathrm{W} 2(\mathrm{~g})-\mathrm{W} 1(\mathrm{~g})$

Specific growth rate $(\mathrm{SGR}):\left\{\mathrm{LnW}_{2}-\mathrm{LnW}_{1}\right\} / \mathrm{t} \times 100$ Where: $\mathrm{Ln}=$ The natural $\log , \mathrm{W}_{1}=$ The intial weight, $\mathrm{W}_{2}=$ The final weight and $\mathrm{t}=$ period in days

Feed conversion ratio $(\mathrm{FCR})=$ Feed intake $(\mathrm{g}) /$ weight gain $(\mathrm{g})$

Statistical analysis:

Statistical analysis of the obtained data was analyzed according to SAS (1996). Differences between means were tested for significance according to Duncan's multiple rang test as described by Duncan (1955).

\section{RESULTS AND DISCUSSION}

\section{Body weight (BW)}

Results of Table 2 showed that, the average BW of Nile tilapia fry ranged between 4.19 and $4.23 \mathrm{~g}$ with insignificant differences between the different experimental groups. After one month growing period the average BW of preexposured fry ranged between 33.53 and $60.29 \mathrm{gm}$ and the differences between these means were significant $(\mathrm{P}<0.001)$. The highest $\mathrm{BW}$ for Nile tilapia fry treated for one week $(60.29 \mathrm{~g})$ was obtained for fry pre-exposured to $35^{\circ} \mathrm{C}$ and fed the diet supplemented by $60 \mathrm{mg} 17 \alpha-\mathrm{MT}$ for one week and the lowest final BW (33.53 gm) was obtained for the control fry group (reared at $25^{\circ} \mathrm{C}$ and fed the diet free from $17 \alpha-$ MT). The highest BW of Nile tilapia fry treated for two weeks $(68.72 \mathrm{~g})$ was obtained for fry pre-exposured to $35^{\circ} \mathrm{C}$ and fed $60 \mathrm{mg} 17 \alpha$-MT supplemented diet and the lowest final BW (34.89 g) was obtained for the control fry group (reared at $25^{\circ} \mathrm{C}$ and 
fed the diet free from $17 \alpha-\mathrm{MT})$. The same trend was also observed for tilapia fry preexposured by each of water temperature and $17 \alpha-\mathrm{MT}$ for three or four weeks.

Table 2: Effect of water temperature and hormone on body weight (BW) of growing Nile tilapia (g/fish) fry at different treatment periods.

\begin{tabular}{lllllcccc}
\hline & \multicolumn{2}{c}{$\begin{array}{c}\text { Fry treated for } \\
\text { one week }\end{array}$} & \multicolumn{2}{c}{$\begin{array}{c}\text { Fry treated for } \\
\text { two weeks }\end{array}$} & \multicolumn{2}{c}{$\begin{array}{c}\text { Fry treated for } \\
\text { three weeks }\end{array}$} & \multicolumn{2}{c}{$\begin{array}{c}\text { Fry treated for } \\
\text { four weeks }\end{array}$} \\
\cline { 2 - 9 } Treatments & Initial & Final & Initial & Final & Initial & Final & Initial & Final \\
& $\mathrm{BW}(\mathrm{g})$ & $\mathrm{BW}(\mathrm{g})$ & $\mathrm{BW}(\mathrm{g})$ & $\mathrm{BW}(\mathrm{g})$ & $\mathrm{BW}(\mathrm{g})$ & $\mathrm{BW}(\mathrm{g})$ & $\mathrm{BW}(\mathrm{g})$ & $\mathrm{BW}(\mathrm{g})$ \\
\hline $\mathrm{C} 25 \mathrm{H} 0$ & 4.19 & $33.53 \mathrm{f}$ & 4.25 & $34.89 \mathrm{f}$ & 4.24 & $33.66 \mathrm{f}$ & 4.26 & $33.90 \mathrm{e}$ \\
$\mathrm{C} 25 \mathrm{H} 1$ & 4.19 & $37.69 \mathrm{e}$ & 4.20 & $42.92 \mathrm{e}$ & 4,23 & $51.59 \mathrm{e}$ & 4.20 & $58.21 \mathrm{~d}$ \\
$\mathrm{C} 30 \mathrm{H} 0$ & 4.23 & $45.30 \mathrm{~d}$ & 4.44 & $49.31 \mathrm{~d}$ & 4.32 & $58.73 \mathrm{~d}$ & 4.32 & $66.77 \mathrm{c}$ \\
$\mathrm{C} 30 \mathrm{H} 1$ & 4.24 & $55.70 \mathrm{~b}$ & 4.21 & $60.31 \mathrm{~b}$ & 4.18 & $71.55 \mathrm{~b}$ & 4.24 & $66.77 \mathrm{c}$ \\
$\mathrm{C} 35 \mathrm{H} 0$ & 4.19 & $48.54 \mathrm{c}$ & 4.20 & $52.59 \mathrm{c}$ & 4.19 & $66.72 \mathrm{c}$ & 4.26 & $70.49 \mathrm{~b}$ \\
$\mathrm{C} 35 \mathrm{H} 1$ & 4.21 & $60.29 \mathrm{a}$ & 4.25 & $68.72 \mathrm{a}$ & 4.19 & $76.55 \mathrm{a}$ & 4.25 & $84.09 \mathrm{a}$ \\
$\mathrm{SE}$ & \pm 0.12 & \pm 0.35 & \pm 0.14 & \pm 0.39 & \pm 0.13 & \pm 0.40 & \pm 0.13 & \pm 0.51 \\
\hline
\end{tabular}

Means followed by different letters in each column for each treat for each trait significantly different $(\mathrm{P}<0.05)$.

With regard to the effect of pre-exposured rearing period, results indicated that, final $\mathrm{BW}$ of control tilapia fry group $(\mathrm{C} 25 \mathrm{H} 0)$ are relatively the same and found to be $33.53,34.89$. 33.66 and 33.90 gm for fry groups treated by normal water temperature $25^{\circ} \mathrm{C}$ and fed the diets free from $17 \alpha$-MT for $1,2,3$ or 4 weeks of treatment periods.

On the other hand, fry group $\mathrm{C} 35 \mathrm{H} 1$ (fry treated by high water temperature $35^{\circ} \mathrm{C}$ and fed the diets supplemented by $17 \alpha-\mathrm{MT}$ ) final BW found to be $60.29,68.72,76.55$ and $84.09 \mathrm{~g}$ for fry groups pre-exposured for 1, 2, 3 or 4 weeks, respectively.

The obtained results indicated that, for control fry group $(\mathrm{C} 25 \mathrm{H} 0)$ rearing periods $(1,2,3$ or 4 weeks) did not affect the final BW of growing Nile tilapia fry while, increasing rearing period $(1,2,3$ or 4 weeks) for $\mathrm{C} 35 \mathrm{H} 1$ gradually increased final BW $(60.29,68.72,76.55$ and $84.09 \mathrm{~g})$ and this result may be attributed to increasing male percentage with increasing treatment period (by water temperature and $17 \alpha-\mathrm{MT}$.

Previous studies have been conducted in this area most of their results come in agreement with the current results. Guerrero (1975) found that the mean weights of hormone treated fry at harvest were generally higher than that of the control $O$. aureus. Also, Guerrero (1979) reported a higher yield in MT-treated groups of $O$. mossambicus over control, and Macintosh et al., (1985) found that, there were significant differences between fry treated and untreated. They obtained an average weight increase of $64 \%$ over controls when feeding $O$. mossambicus fry with MT-30 mg for 60 days.

Also, McAndrew and Majundar (1989) obtained 25.7\% increase in weight over controls when $O$. niloticus fry were treated with MT-40 for 40 days. Varadaraj (1990) observed that the increase in mean body weight of fry treated with 19-norethisterone acetate than control for 15 days by be attributed to the anabolic effect of 19-NE on metabolism. Khater (1998) indicated that, $O$. niloticus fry treated with different doses of $17 \alpha-\mathrm{MT}(0,15,30,60$ and $90 \mathrm{mg} / \mathrm{kg}$ diet $)$ for different periods $(14,21$ and 28 days) had significantly higher BW as compared to the control group which received no hormone in their diet $(\mathrm{P}<0.05)$. In this respect, Ferdous and Ali (2011) indicated that, the dose of $60 \mathrm{mg} \mathrm{MT} / \mathrm{kg}$ of feed resulted in maximum male population (94.28\%) of $O$. niloticsu fry with a feeding period of 28 days after hatching.

\section{Body length (BL)}

Results of Table 3 showed that the average BL of $O$. niloticus fry ranged between 5.77 and $6.25 \mathrm{~cm}$ with insignificant differences between the different experimental groups. After one month growing period the average BL of pre- 
exposured tilapia fry for one week ranged between 11.07 and $15.38 \mathrm{~cm}$ and the differences between these means were significant $(\mathrm{P}<0.001)$.

Table 3: Effect of water temperature and hormone on body length (BL) of growing Nile tilapia (cm/fish) fry at different treatment periods.

\begin{tabular}{|c|c|c|c|c|c|c|c|c|}
\hline \multirow[t]{2}{*}{ Treatments } & \multicolumn{2}{|c|}{$\begin{array}{l}\text { Fry treated for one } \\
\text { week }(\mathrm{cm})\end{array}$} & \multicolumn{2}{|c|}{$\begin{array}{l}\text { Fry treated for two } \\
\text { weeks }(\mathrm{cm})\end{array}$} & \multicolumn{2}{|c|}{$\begin{array}{l}\text { Fry treated for three } \\
\text { weeks }(\mathrm{cm})\end{array}$} & \multicolumn{2}{|c|}{$\begin{array}{l}\text { Fry treated for four weeks } \\
\qquad(\mathrm{cm})\end{array}$} \\
\hline & $\begin{array}{c}\text { Initial } \\
\mathrm{BL}\end{array}$ & $\begin{array}{c}\text { Final } \\
\text { BL }\end{array}$ & $\begin{array}{c}\text { Initial } \\
\mathrm{BL}\end{array}$ & $\begin{array}{c}\text { Final } \\
\text { BL }\end{array}$ & Initial BL & $\begin{array}{c}\text { Final } \\
\text { BL }\end{array}$ & Initial BL & $\begin{array}{c}\text { Final } \\
\text { BL }\end{array}$ \\
\hline $\mathrm{C} 25 \mathrm{H} 0$ & 5.80 & $11.07 \mathrm{e}$ & 5.89 & $11.00 \mathrm{f}$ & 5.80 & $11.07 \mathrm{e}$ & 5.26 & $11.04 \mathrm{e}$ \\
\hline $\mathrm{C} 25 \mathrm{H} 1$ & 5.78 & $11.84 \mathrm{~d}$ & 6.18 & $13.00 \mathrm{e}$ & 5.95 & $13.73 \mathrm{~d}$ & 5.25 & $14.45 \mathrm{~d}$ \\
\hline $\mathrm{C} 30 \mathrm{HO}$ & 5.88 & $12.33 \mathrm{c}$ & 5.76 & $14.31 \mathrm{c}$ & 5.93 & $16.65 \mathrm{c}$ & 5.31 & $17.36 \mathrm{~b}$ \\
\hline C30H1 & 5.77 & $13.40 \mathrm{~b}$ & 6.03 & $15.38 \mathrm{~b}$ & 5.97 & $17.40 \mathrm{~b}$ & 5.23 & $17.36 \mathrm{~b}$ \\
\hline $\mathrm{C} 35 \mathrm{H} 0$ & 5.78 & $11.90 \mathrm{~d}$ & 6.18 & $13.82 \mathrm{~d}$ & 5.80 & $16.91 \mathrm{c}$ & 5.26 & $16.28 \mathrm{c}$ \\
\hline C35H1 & 6.25 & $15.38 \mathrm{a}$ & 5.85 & $17.11 \mathrm{a}$ & 5.80 & $18.16 \mathrm{a}$ & 5.20 & $18.32 \mathrm{a}$ \\
\hline SE & \pm 0.08 & \pm 0.10 & \pm 0.09 & \pm 0.10 & \pm 0.09 & \pm 0.11 & \pm 0.13 & \pm 0.10 \\
\hline
\end{tabular}

Means followed by different letters in each column for each treat for each trait significantly different $(\mathrm{P}<0.05)$.

The highest BL of Nile tilapia fry treated for one week $(15.38 \mathrm{~cm})$ was obtained for fry pre-exposured to $35^{\circ} \mathrm{C}$ and fed the diet supplemented by $60 \mathrm{mg} 17 \alpha$-MT for one week and the lowest final BL $(11.07 \mathrm{~cm})$ was obtained for the control fry group (reared at $25^{\circ} \mathrm{C}$ and fed the diet free from $17 \alpha$-MT for one week). Also, the highest BL of Nile tilapia fry treated for two weeks $(17.11 \mathrm{~cm})$ was obtained for fry preexposured to $35^{\circ} \mathrm{C}$ and fed the diet supplemented by $60 \mathrm{mg} 17 \alpha$-MT for two weeks and the lowest final BL $(13 \mathrm{~cm})$ was obtained for the control fry group (reared at $25^{\circ} \mathrm{C}$ and fed the diet free from $17 \alpha-\mathrm{MT}$ ) and the same trend was also observed for tilapia fry pre-exposured to each of water temperature and 17 $\alpha$-MT for three or four weeks.

With regard to the effect of previously rearing period, results also indicated that, final $\mathrm{BL}$ of control tilapia fry group $(\mathrm{C} 25 \mathrm{H} 0)$ are relatively the same and found to be $11.07,11.00 .11 .07$ and $11.04 \mathrm{~cm}$ for fry groups treated by normal water temperature $25^{\circ} \mathrm{C}$ and fed the diets free from $17 \alpha-\mathrm{MT}$ for $1,2,3$ or 4 weeks of treatment periods, respectively. On the other hand, fry group $\mathrm{C} 35 \mathrm{H} 1$ (fry treated by high water temperature $35^{\circ} \mathrm{C}$ and fed the diets supplemented by $17 \alpha-\mathrm{MT}$ ) final BL found to be $15.38,17.11,18.16$ and $18.32 \mathrm{~cm}$ for fry groups pre-exposured for $1,2,3$ or 4 weeks, respectively.

The obtained results indicated that, for control fry group rearing periods $(1,2,3$ or 4 weeks) did not affect the final BL of growing Nile tilapia fry while, increasing rearing period for $\mathrm{C} 35 \mathrm{H} 1$ gradually increased final $\mathrm{BL}$ (15.38, 17.11, 18.16 and 18.32 $\mathrm{cm})$ and this result may be attributed to increasing male percentage with increasing treatment period (by water temperature and 17 $\alpha$-MT.

The current results are in agreement with those reported by Khater (1998) who indicated that, $O$. niloticus fry treated with different doses of $17 \alpha$-MT $(0,15,30,60$ and $90 \mathrm{mg} / \mathrm{kg}$ diet) for different periods (14, 21 and 28 days) had significantly higher $\mathrm{BL}$ as compared to the control group which received no hormone in their diet $(\mathrm{P}<0.05)$. In this respect Jensen and Shelton (1979) found that, the mean body length ranged from 1.7 to $1.8 \mathrm{~cm}$ when $O$. aureus fry received estradiol for 21 days and they attributed this result to water temperature and hormone $17 \alpha$ methyltestosterone.

\section{Weight gain (WG)}

With respect of the interaction between water temperature and $17 \alpha-\mathrm{MT}$, results of Table 4 showed that, the average WG of Nile tilapia fry ranged between 28.77 and $54.87 \mathrm{~g}$ with significant differences between the different experimental fry groups after one month growing period for pre-exposured tilapia fry. The highest WG $(54.87$ g) was obtained for fry pre-exposured to $35^{\circ} \mathrm{C}$ and fed the diet supplemented by $60 \mathrm{mg}$ 
$17 \alpha$-MT for one week and the lowest WG (28.77 g) was obtained for the control fry group (reared at $25^{\circ} \mathrm{C}$ and fed the diet free from $17 \alpha-\mathrm{MT}$ ). The same trend was also observed for tilapia fry previously treated by each of water temperature and $17 \alpha-\mathrm{MT}$ for two, three or four weeks.

With regard to the effect of previously rearing period, results also indicated that, WG of control tilapia fry group $(\mathrm{C} 25 \mathrm{H} 0)$ are relatively the same and found to be 28.77 , $33.5,26.40$ and 30.92 gm for fry groups treated by normal water temperature $25^{\circ} \mathrm{C}$ and fed $17 \alpha$-MT free diet for 1, 2, 3 or 4 weeks of treatment periods, respectively. On the other hand, fry treated by high water temperature $35^{\circ} \mathrm{C}$ and fed $17 \alpha$-MT supplemented supplemented diet $(\mathrm{C} 35 \mathrm{H} 1)$, WG found to be 53.87, 63.95, 71.97 and $79.46 \mathrm{~g}$ for fry groups pre-exposured for 1, 2, 3 or 4 weeks, respectively.

Table 4: Effect of temperature and hormone on fry weight gain (WG) of Nile tilapia (g/fish)) at different treatment periods.

\begin{tabular}{lllll}
\hline Treatments & $\begin{array}{r}\text { Fry treated for one } \\
\text { week }(\mathrm{g})\end{array}$ & $\begin{array}{r}\text { Fry treated for two } \\
\text { weeks }(\mathrm{g})\end{array}$ & $\begin{array}{c}\text { Fry treated for three } \\
\text { weeks }(\mathrm{g})\end{array}$ & $\begin{array}{c}\text { Fry treated for four } \\
\text { weeks }(\mathrm{g})\end{array}$ \\
\hline $\mathrm{C} 25 \mathrm{H} 0$ & $28.77 \mathrm{~d}$ & $33.50 \mathrm{e}$ & $26.40 \mathrm{e}$ & $30.92 \mathrm{~d}$ \\
$\mathrm{C} 25 \mathrm{H} 1$ & $33.30 \mathrm{c}$ & $38.55 \mathrm{de}$ & $44.86 \mathrm{~d}$ & $58.85 \mathrm{c}$ \\
$\mathrm{C} 30 \mathrm{H} 0$ & $39.21 \mathrm{~b}$ & $43.99 \mathrm{~cd}$ & $56.77 \mathrm{c}$ & $60.45 \mathrm{c}$ \\
$\mathrm{C} 30 \mathrm{H} 1$ & $51.10 \mathrm{a}$ & $54.82 \mathrm{~b}$ & $68.03 \mathrm{a}$ & $62.16 \mathrm{bc}$ \\
$\mathrm{C} 35 \mathrm{H} 0$ & $43.28 \mathrm{~b}$ & $47.17 \mathrm{c}$ & $62.15 \mathrm{~b}$ & $66.81 \mathrm{~b}$ \\
$\mathrm{C} 35 \mathrm{H} 1$ & $54.87 \mathrm{a}$ & $63.95 \mathrm{a}$ & $71.97 \mathrm{a}$ & $79.46 \mathrm{a}$ \\
$\mathrm{SE}$ & \pm 1.30 & \pm 1.83 & \pm 1.59 & \pm 1.89 \\
\hline
\end{tabular}

Means followed by different letters in each column for each treat for each trait significantly different $(\mathrm{P}<0.05)$.

The obtained results indicated that, for control fry group rearing periods $(1,2,3$ or 4 weeks) did not affect the average WG of growing Nile tilapia fry while, increasing rearing period for $\mathrm{C} 35 \mathrm{H} 1$ gradually increased the average WG (53.87, 63.95, 71.97 and $79.46 \mathrm{~g}$ ) and this result may be attributed to increasing male percentage with increasing treatment period (by water temperature and 17 $\alpha$-MT. Baras et al., (2001) noticed depression in tilapia growth reared at $37^{\circ} \mathrm{C}$ and they attributed the depressed growth at $37^{\circ} \mathrm{C}$ to the increase of routine metabolism and reduction of the scope for activity at temperatures above the optimum. They also added that, growth depression was proportionally lower during the first 14 days of exogenous feeding than in older fish, probably because the optimum temperature for growth decreased in the course of ontogenetic development.

\section{Specific growth rate (SGR):}

After one month growing period SGR of previously treated tilapia fry for one week ranged between 2.17 to $2.85 \%$ and the differences between these means were significant $(\mathrm{P}<0.001)$. The highest SGR value $(2.85 \%)$ was obtained for fry preexposured to $35^{\circ} \mathrm{C}$ and fed $17 \alpha-\mathrm{MT}$ supplemented diet for one week and the lowest SGR $(2.17 \%)$ was obtained for the control fry group (reared at $25^{\circ} \mathrm{C}$ and fed the $17 \alpha$ MT free diet for one week).

Results of Table 5 also showed that, after one month growing period, the highest SGR (2.97\%) was obtained for fry pre-exposured to $35^{\circ} \mathrm{C}$ and fed $17 \alpha-\mathrm{MT}$ supplemented diet for two weeks and the lowest SGR value $(2.34 \%)$ was obtained for the control fry group (reared at $25^{\circ} \mathrm{C}$ and fed the $17 \alpha$-MT free diet for two weeks) and the same trend was also observed for tilapia fry pre-exposured to each of water temperature and $17 \alpha-\mathrm{MT}$ for three or four weeks. 
Table 5: Effect of graded levels of water temperature and hormone on fry specific growth rate (SGR) of Nile tilapia (\%/day) at different treatment periods.

\begin{tabular}{lllll}
\hline Treatments & $\begin{array}{c}\text { Fry treated for } \\
\text { one week }(\% / \mathrm{d})\end{array}$ & $\begin{array}{c}\text { Fry treated for } \\
\text { two weeks }(\% / \mathrm{d})\end{array}$ & $\begin{array}{c}\text { Fry treated for } \\
\text { three weeks }(\% / \mathrm{d})\end{array}$ & $\begin{array}{c}\text { Fry treated for } \\
\text { four weeks }(\% / \mathrm{d})\end{array}$ \\
\hline $\mathrm{C} 25 \mathrm{H} 0$ & $2.17 \mathrm{~d}$ & $2.34 \mathrm{e}$ & $2.14 \mathrm{e}$ & $2.23 \mathrm{c}$ \\
$\mathrm{C} 25 \mathrm{H} 1$ & $2.38 \mathrm{c}$ & $2.52 \mathrm{~d}$ & $2.65 \mathrm{~d}$ & $2.92 \mathrm{~b}$ \\
$\mathrm{C} 30 \mathrm{H} 0$ & $2.56 \mathrm{~b}$ & $2.60 \mathrm{~d}$ & $2.88 \mathrm{c}$ & $2.97 \mathrm{~b}$ \\
$\mathrm{C} 30 \mathrm{H} 1$ & $2.78 \mathrm{a}$ & $2.83 \mathrm{~b}$ & $3.07 \mathrm{ab}$ & $2.97 \mathrm{~b}$ \\
$\mathrm{C} 35 \mathrm{H} 0$ & $2.61 \mathrm{~b}$ & $2.71 \mathrm{c}$ & $2.97 \mathrm{bc}$ & $3.02 \mathrm{~b}$ \\
$\mathrm{C} 35 \mathrm{H} 1$ & $2.85 \mathrm{a}$ & $2.97 \mathrm{a}$ & $3.09 \mathrm{a}$ & $3.22 \mathrm{a}$ \\
$\mathrm{SE}$ & \pm 0.03 & \pm 0.03 & \pm 0.03 & \pm 0.04 \\
\hline
\end{tabular}

Means followed by different letters in each column for each treat for each trait significantly different $(\mathrm{P}<0.05)$.

With regard to the effect of pre-exposured rearing period, results also indicated that, SGR for control tilapia fry group $(\mathrm{C} 25 \mathrm{H} 0)$ are relatively the same and found to be $2.17,2.34,2.14$ and $2.23 \%$ for fry groups treated by normal water temperature $25^{\circ} \mathrm{C}$ and fed the $7 \alpha$-MT free diet for 1, 2, 3 or 4 weeks of treatment periods, respectively. On the other hand, fry group $\mathrm{C} 35 \mathrm{H} 1$ (fry treated by high water temperature $35^{\circ} \mathrm{C}$ and fed the $17 \alpha$-MT supplemented diet), SGR found to be $2.85,2.97,3.09$ and $3.22 \%$ for fry groups pre-exposured for 1, 2, 3 or 4 weeks, respectively.

The obtained results indicated that, for control fry group rearing periods (1, 2, 3 or 4 weeks) did not affect the SGR of growing Nile tilapia fry while, increasing rearing period for $\mathrm{C} 35 \mathrm{H} 1$ gradually increased final SGR $(2.85,2.97,3.09$ and 3.22\%) and this result may be attributed to increasing male percentage with increasing treatment period (by water temperature and $17 \alpha-\mathrm{MT}$.

Treated fish groups (by hormone or temperature) the current study showed an improvement in SGR compared with mixed sex of Nile tilapia obtained in previous studies (Abdel-Hakim et al., 2001 a \& b; Hassaan et al., 2013 and 2014 a \& b). The obtained results follow the trend as those obtained by McAndrew and Majumdar (1989) who reported that, feeding $O$. aureus fry with MT-40 $\mathrm{mg} / \mathrm{kg}$ feed for a period of 40 days resulted in a significant increase in SGR. Also, Khater (1998) indicated that, O. niloticus fry treated with different doses of $17 \alpha-\mathrm{MT}(0,15,30,60$ and 90 $\mathrm{mg} / \mathrm{kg}$ diet) for different periods (14, 21 and 28 days) had significantly higher SGR as compared to the control group which received no hormone in their diet $(\mathrm{P}<0.05)$. Also, Beaven and Muposhi (2012) indicated that O. nioticus fry fed a diet treated with MT had significantly higher growth rate as compared to those fed to a non hormone treated diet.

For other fish species, Woo et al., (1993) found that, there were significant differences in SGR between testosterone treated and untreated red sea bream, Chrysophrys major, and they attributed this result to the fact that the testosterone has anabolic effects on the red sea bream because it increase appetite, the activities enzymes and feed conversion efficiency.

\section{Feed conversion ratio (FCR):}

The average FCR of Nile tilapia fry ranged between 1.91 to 2.07 with insignificant differences $(\mathrm{P}>0.05)$ between the different fry groups pre-exposured for one week after one month of growing period. Results of Table 6 also showed that the worst FCR (2.07) was obtained for fry pre-exposured to $35^{\circ} \mathrm{C}$ and fed the $17 \alpha$-MT free diet for one week and the best FCR (1.91) was obtained for fry group reared at $25^{\circ} \mathrm{C}$ and fed the diet $17 \alpha-$ MT supplemented diet for one week and the same trend was also observed for FCR at all rearing periods $1,2,3$ and 4 weeks. 
Table 6: Effect of graded levels of water temperature and hormone on fry feed conversion ratio (FCR) of Nile tilapia at different treatment periods.

\begin{tabular}{ccccc}
\hline Treatments & $\begin{array}{c}\text { Fry treated for one } \\
\text { week }\end{array}$ & $\begin{array}{c}\text { Fry treated for two } \\
\text { weeks }\end{array}$ & $\begin{array}{c}\text { Fry treated for three } \\
\text { weeks }\end{array}$ & Fry treated for four weeks \\
\hline C25H0 & 1.92 & 2.01 & $1.86 \mathrm{ab}$ & $1.75 \mathrm{~b}$ \\
$\mathrm{C} 25 \mathrm{H} 1$ & 1.91 & 1.86 & $1.94 \mathrm{a}$ & 1.77 \\
$\mathrm{C} 30 \mathrm{H} 0$ & 1.77 & 1.94 & $1.83 \mathrm{ab}$ & 1.89 \\
$\mathrm{C} 30 \mathrm{H} 1$ & 2.02 & 1.85 & $1.84 \mathrm{ab}$ & 1.79 \\
$\mathrm{C} 35 \mathrm{H} 0$ & 2.07 & 1.97 & $1.79 \mathrm{ab}$ & 1.77 \\
$\mathrm{C} 35 \mathrm{H} 1$ & 2.03 & 1.88 & \pm 0.04 \\
$\mathrm{SE}$ & \pm 0.09 & \pm 0.09 & \pm 0.08 \\
\hline
\end{tabular}

Means followed by different letters in each column for each treat for each trait significantly different $(\mathrm{P}<0.05)$.

The present results do not agreed with those obtained by Khater (1998). He found that, FCR of $O$. niloticus fry treated with different doses of $17 \alpha-\mathrm{MT}(0,15,30$, 60 and $90 \mathrm{mg} / \mathrm{kg}$ diet) for 14 days were $1.421 .11,1.23,1.08$ and 1.05 , respectively. There were no significant differences among all hormone-treated groups. However, they were significant different from the control group $(\mathrm{P}<0.05)$ which received hormone-free diets. Similar results were also observed for protein efficiency ratio. Matty and Lone (1979) and Lone and Matty (1980 \& 1981) demonstrated that natural androgens and MT treatment enhanced the feed efficiency values in common carp, Cyprinus carpio L. Also, Phelps et al., (1992) obtained similar results when $O$. niloticus fry was fed the diet treated with MT at $60 \mathrm{mg} / \mathrm{kg}$ of feed for 28 days.

Variations in the growth rates in this study may also be attributed to the differences in the feed conversion ratios of fry groups. High FCR values for individuals whose diet was androgenised may have contributed to better conversion of feed and the consequent weight gain as compared to the other group. $17 \alpha$-MT is an accelerator of mineral uptake into the body as well as their retention and hence males are likely to have a better conversion of food (Falany and Falany, 1996 \& Beaven and Muposhi 2012).

Although we observed a relatively high feed conversion ratio in individuals, with diet was androgenised diets than the ones without, the FCR established in this study are rather low as compared to the findings of Watanabe (2000), Soltan et al., (2002 \& 2006) Abou Zead et al., (2008). This could have been due to the fact that the hormone can degrade during storage and on its passage through the digestive tract. Furthermore, the lack of uniformity of the hormone in the feed and hierarchies among fish can cause significant variability in dose among treated individuals making estimates of amounts ingested very difficult. Excessive doses of some hormones can lead to sterility or paradoxical feminization following aromatization of androgens to estrogen.

\section{REFERENCES}

Abdel-Hakim, N. F.; Bakeer, M. N. and Soltan, M. A. (2001 a). Effect of dietary protein levels on growth performance and pond productivity of Nile tilapia (Oreochromis niloticus), Eel (Anguilla anguilla) and Grey mullet (Mugil cephalus) reared in polyculture system. Egypt. J. Aquat. Biol. \& Fish. 5 (4):61-85.

Abdel-Hakim, N. F.; Hussein, M. S.; Bakeer, M. N. and Soltan, M. A. (2001b). Effect of protein level and stocking density on growth performance of Nile tilapia (Oreochromis niloticus) cultured in tanks. Egypt J. Nutrition and Feeds 4:763780.

Abdel-Hakim, N. F.; Soltan, M. A. and Bakeer, M. N. (2000). Induction of diploid androgenetic Nile tilapia (Oreochromis niloticus). Egyptian J. Aquat. Biol \& Fish. 4 (4):337-349. 
Abou Zead, M. Y.; Soltan, M. A. and Ibrahim, M. S. (2008). Effect of replacing Soybean meal by sunflower meal in the diets of Nile tilapia, Oreochromis niloticus. (L.). Proceeding of the $8^{\text {th }}$ International Symposium on Tilapia in Aquaculture, 12-14/10/2008, Cairo, Egypt. pp.787-799.

Balarin, J.D. and Hatton, J.P. (1979). Tilapia. A Guide to Their Biology and Culture in Africa. Unit of Aquatic Pathobiology, University of Stirling, Scotland.

Baras, E., Jacobs, B. and Melard, C. (2001). Effect of water temperature on survival, growth and phenotypic sex of mixed (XX-XY) progenies of Nile tilapia Oreochromis niloticus. Aquacult, 192:187-199.

Baras, E.; Prignon, C.; Gohoungo, G. and Melard, C. (2000). Phenotypic sex differentiation of blue tilapia under constant and fluctuating thermal regimes and its adaptive and evolutionary implications. J. Fish Biol., 57:210-223.

Baroiller, J.F.; Fostier, A.; Cauty, C.; Rognon, X. and Jalabert, B. (1996a). Effect of high rearing temperature on the sex ratio of progeny from sex-reversed males of Oreochromis niloticus. In: Pullin, R.S.V., Lazard, J., Legendre, M., Amon kothias, J.B., Pauly, D. (Eds.), Proceedings of the Third Symposium on tilapia in Aquaculture. ICLARM Conference Proceedings, vol. 41, pp. 246-256.

Baroiller, J.F., Clota, F., Geraz, E. (1996b). Temperature sex determination in two tilapias species, Oreochromis niloticus and the red tilapia (Red Florida strain): effect of high or low temperatures. In: Goetz, F., Thomas, P. (Eds.), Proceeding of the Fifth International Symposium on the Reproductive Physiology of Fish, Austin, TX, pp. 158-160.

Baroiller, J.F.; Chourrout, D.; Fostier, A. and Jalabert, B. (1995). Temperature and sex chromosomes govern sex ratios of the mouthbrooding Cichlid fish Oreochromis niloticus. J. Exp. Zool. 273, 216-223.

Beaven, U. and Muposhi, V. (2012). Aspects of a Monosex Population of Oreochromis Niloticus Fingerlings Produced Using 17-a Methyl Testosterone Hormone. J. Aquacult Res. Dev., 3:132-137.

Duncan, M. B. (1955). Multiple ranges and multiple F-tests. Biometrics,11:1-42.

Falany, J. L. and Falany, C. N. (1996). Regulation of estrogen sulfotransferase in human endometrial adenocarcinoma cells by progesterone. Endocrinology, 137: 13951401.

Ferdous, Z. and Ali, M. M. (2011). Optimization of hormonal dose during masculinization of tilapia (Oreochromis niloticus) fry. J. Bangladesh Agril. Univ., 9(2):85-364.

Guerrero III R. D. (1982). Control of tilapia reproduction: In RSV Pullin, RH Lowe McConnell, eds. The Biology and Culture of Tilapias. ICLARM Conference Proceedings 7. International Center for Living Resources Management, Manila, Philippines, pp.309-316.

Gurerrero III R. D. (1979). Culture of male Tilapia mossambicus produced through artificial sex reversal. In Advances in Aquaculture. (ed. By T. V. R. Pillay) \& W. A. Dill). Pp. 166-168 fishing Books Ltd. Farnham.

Gurerrero III R. D. (1975). Use of androgens for the production of all-male Tilapia aurea. (Steindachner). Amer. Fish. Soc., 104(2):342-348.

Guerrero III R.D. and Guerrero, L.A. (1988). Feasibility of commercial production of Nile tilapia fingerlings in Philippines: In RSV Pullin, T Bhukaswan, K Tonguthai, JL Maclean, eds. The Second International Symposium on Tilapia in Aquacul-ture. ICLARM Conference Proceedings 15, Department of Fisheries, Bangkok, Thailand, and International Center for Living Aquatic Resources Management, Manila, Philippines, 183-186. 
Hassaan, M. S.; Wafa, M. A.; Soltan, M. A.; Goda, A. S. and Mogheeth, N. M. A. (2014 a). Effect of Dietary Organic Salts on Growth, Nutrient Digestibility, Mineral Absorption and Some Biochemical Indices of Nile Tilapia; Oreochromis niloticus L. Fingerlings. World Appl Scie J, 29(1):47-55.

Hassaan, M. S.; Soltan, M. A. and Ghonemy, M. M. R. (2014b). Effect of synbiotics between Bacillus licheniformis and yeast extract on growth, hematological and biochemical indices of the Nile tilapia Oreochromis niloticus. The Egypt J Aquat Rese. 40:199-208.

Hassaan, M. S.; Soltan, M. A.; Agouz, H. M. and Badr, A. M. (2013). Influences of calcium/phosphorus ratio on supplemental microbial phytase efficiency for Nile tilapia (Oreochromis niloticus). Egypt Aquatic Rese, 39:205-213.

Hickling, C. F. (1960). The Malacca tilapia hybrids. J Genet 57: 1-10.

Jensen, G. L. and Shelton, W. L. (1979). Effects of estrogens on Tilapia aurea: implications for production of monosex genetic male tilapia. Aquaculture, 16:233-242.

Khater, A. M. M. (1998). Sex reversal in tilapia nilotica. Ph. D Thesis, Faculty of Agriculture, Zagazig University.

Lone, K. P. and Matty, A. J. (1981). The effect of feeding androgen hormones of carp Cyprinus carpio L. J. Fish Biol., 20:93-104.

Lone, K. P. and Matty, A. J. (1980). The effect of feeding methyltestosterone on the growth and body composition of common carp (Cyprinus carpio L.) Gen. Comp. Endocrinol., 40:309-424.

Macintosh, D. L.; Varghese, T. J. and Satyanarayana Rao, G. P. (1985). Hormonal sex reversal of wild spawned tilapia in India. J. Fish Biol., 26:87-94.

Matty, A. J. and Lone, K. P. (1979). Sex steroids as food additives for Cyprinus carpio. Proceedings of the world mariculture Society, 10:735-745.

McAndrew, B. J. and Majumdar, K. C. (1989). Growth studies on juvenile tilapia using pure species, hormone-treated and nine interspecific hybrids. Aquacult Rese, 20(1), 35-48.

Melard, C., (1986). Les bases biologiques de l'elevage du tilapia du Nil. Cah. Ethol. Appl. 6:1-224.

Pandian, T. J. abd Varadaraj, K. (1988). Techniques for producing all male and all-triploid Oreochromis mossambicus: In RSV Pullin, T Bhukaswan, K Tonguthai, JL Maclean, eds. The Second International Symposium on Tilapia in Aquaculture. ICLARM Conference Proceedings 15. Department of Fisheries, Bangkok, Thailand, and International Center for Living Aquatic Resources Management, Manila, Philippines, 243-249.

Phelps, R. P.; Cole, W. and Katz, T. (1992). Effect of fluoxymeserone on sex ratio and growth of Nile tilapia, Oreochromis niloticus. Aquacult Fish Manag, 23:405-410.

SAS (1996). SAS Procedure Guide "version 6.12 Ed". SAS Institute Inc., Cary, NC, USA.

Soltan, M. A.; Hassan, M. S.,; El-Nagaar, G. O. and Mohammed, W. E. (2013): Effect of rearing temperature and hormone treatment on sex ratio, survival and body weight of Oreochromis niloticus fry. Egypt. J. Aquat., Biol., \& Fish., 17(4):13-23.

Soltan, M. A., Mohamed, K. A. and Eid, A. H. (2006): Effect of protein to energy ratio on growth performance and body composition of red tilapia reared in freshwater. J the Egyp Aquacult Socie, 1:57-68.

Soltan, M. A.; Radwan, A. A. and Samra, I. M. (2002). Effect of varying protein, energy and protein to energy ratio on growth, feed efficiency and body 
composition of Nile tilapia, Oreochromis niloticus. $1^{\text {st }}$ Annual Conference of the Egyptian Aquaculture Society, Al-Arish, North Sinai, Egypt, 13-15 December, 2002.

Soltan, M. A.; Fatma, A. H.; Ibrahim, M. K. and Hörstgen-Shwark, G. (1999). Effect of triploidy induction on maturation and growth traits of Nile tilapia, Oreochromis niloticus. Egyptian J. Aquat. Biol \& Fish., 3 (4):55-72.

Trewavas, E. (1983). Tilapiine Fishes of the Genera Sarotherodon, Oreochromis and Danakilia. British Museum (Natural History), London.

Varadaraj, K. (1990). Production of monosex male Oreochromis mossambicus (Peters) by administering 19-norethisterone acetate. Aquacult Fish Manag 21:133-135.

Watanabe. P. (2000). Relationship of Social Interactions, Stocking Density, and Feeding Frequency on Tilapia Growth Rates, Cambridge University Press, London, 6-12.

Woo, N. Y. S.; Chung, A. A. S. B. and Ng, T. B. (1993). Influence of oral administration of estradiol-17ß and testeosterone on growth, digestion, food conversion and metabolism in underyearling red sea bream, Chrysophrys major. Fish Physiol Biotechnol, 10(5):377-387.

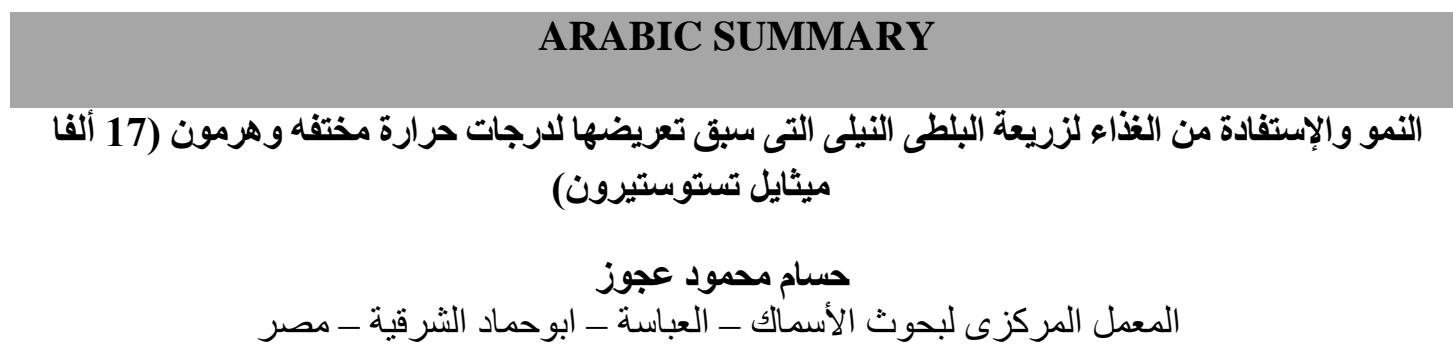

فى دراسة سابقة تم إجر اء تجربة لدراسة تأثثر درجة حرارة الماء مع أو بدون هرمون الذكورة (17 ألفا

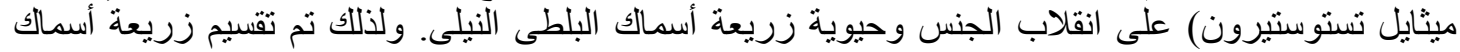

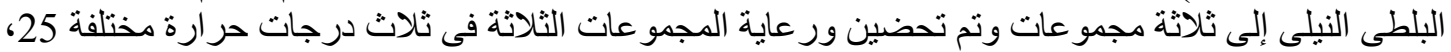

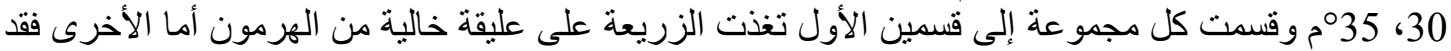

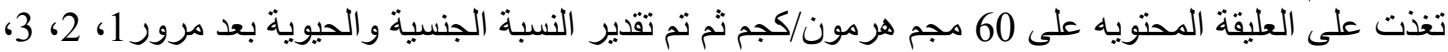

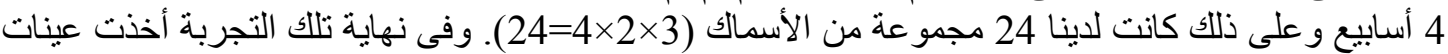

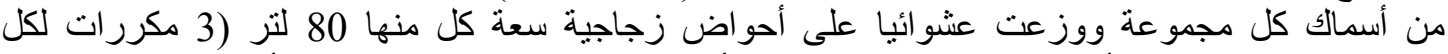

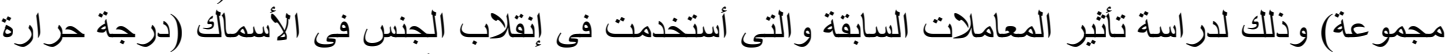

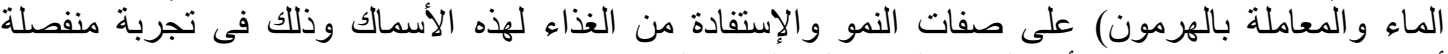

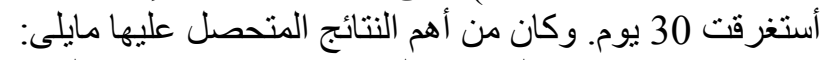

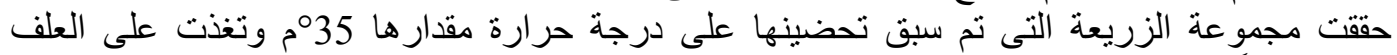

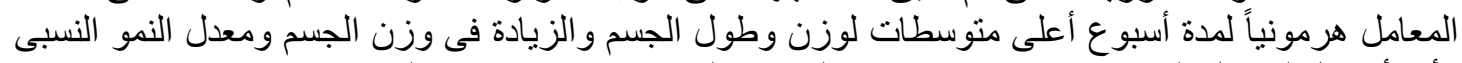

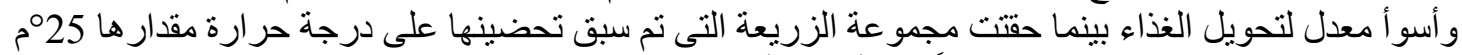

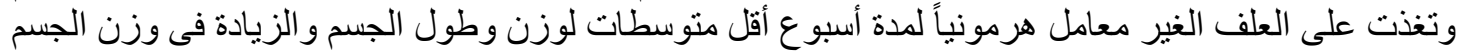

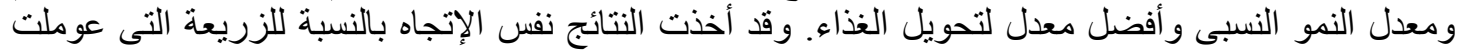

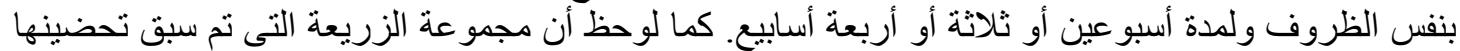

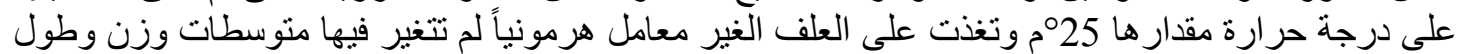

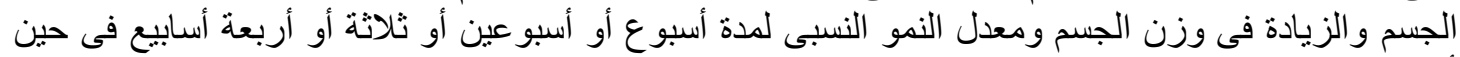

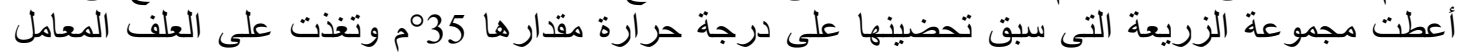
هرمونياً لمدة أسبوع أو أسبو عين أو ثلاثة أو أربعة أسابيع قد أعطت نتائج مخالفة لذللك. 